\title{
3. Suzanne Paul: Scandal, celebrity and the selling of an infomercial queen
}

\section{ABSIRACI}

Infomercial queen, recording artist, bankrupt, dancing victor; Suzanne Paul was a fixture on New Zealand television for more than 15 years and has been celebrated, valorised, critiqued and embraced. Yet, perhaps because of her 'low-end' appeal, Paul's place on our screens has not been rigorously investigated. In this article, we argue that Paul's importance lies in three main areas. First, during the 1990s, she was responsible for the paradigmatic televisual form - the infomercial. Second, she can be understood as a liminal figure, and one who encapsulates the dilemma of cultural production as a 'new New Zealander'. Third, her story offers a case study of how the nominally famous can move from using themselves to sell products to selling themselves as a product - the ultimate selling (of) celebrity. Further, we argue that Paul cannot be understood without reference to the centrality of scandal to her persona and, indeed, narrative as a celebrity. The first 'act' of her career saw the television (and advertising) industry scandalised by her undercutting their standards with cheap, almost deliberately unironic infomercial marketing; the second saw her attempt a transition to the mainstream before a spectacular business failure and bankruptcy; in the third she embraced her disgrace, remodelled her persona and won a reality television dancing programme. Ultimately, we contend that Paul's career depended on a constant interplay between the carefully constructed appeal she projected and her responsibility for, and responses to, a semi-permanent state of scandal.

Keywords: celebrity, cultural production, fame, infomercial, scandal,

ROSSER JOHNSON and NEMANE BIELDT

Auckland University of Technology

PACIFIC JOURNALISM REVIEW 19 (2) 201349 


\section{CELEBRITY AND SCANDAL}

7 HE INFOMERCIAL is a form of television that is typified by its relentless commercial message (the entirety of the broadcast showcases, promotes, or sells the featured product) and its apparently informative, or even educational, appearance (which goes some way to mask its consumerist base). Although it might be possible to describe an infomercial as a 'commercial that looks like it's a programme', the duplicity at the centre of its communicative structure is relatively easy to read, accommodate and react to (Johnson \& Hope, 2004; Johnson, 2013). As Gary Hallberg (1995) notes, despite its prominence in the 1980s and 1990s, infomercial broadcasting first developed in the USA in the 1950s, with a relatively straightforward televisual style where the early infomercial marketers simply transferred the selling techniques of barker-style outdoor demonstrations to television (Adler, 2002). However, infomercials were largely removed from the schedules following the move to magazine (or 'spot') advertising in the 1950s. They were then functionally barred by the Federal Communications Commission (FCC) in the 1970s when it introduced a statutory maximum of advertising minutes per hour (Hutheesing, 1995, p.50), largely because of the popularity of the infomercial with marketers who were targeting children (Balasubramanian, 1994, p.35). The deregulation of broadcasting in the 1980 s, specifically the loosening, and in some cases, removal of statutory maximums for advertising minutes per hour (Bubniak, 1998, p.146; Sivulka, 1998, p.409), removed the formal impediments to the reintroduction of the infomercial (Wojtas, 1990, p.30).

Once the infomercial reappeared on cable, and then terrestrial channels, viewers were presented with a range of personalities who were unashamedly associating themselves with this cheap, low-end form of television. There is no doubt that it was possible for infomercial 'faces' to become part of mainstream popular culture. One obvious example from the early 1990s was Mike Levy, the founder of Positive Response Television, who became a minor celebrity in countries like the Netherlands, Japan and New Zealand. Interestingly, marketers argue that the novelty of the infomercial form combined with its promotion of American products underpinned its appeal outside the USA:

To consumers in Indonesia, the protracted ads are a kind of window on the American dream - and its wondrous array of jerky makers, tooth whiteners, and vertical roasters. Besides, their regular programming isn't that great. (Carvell, 1997, p.36)

50 PACIFIC JOURNALISM REVIEW 19 (2) 2013 
Within the next five years it became increasingly more common for marginal figures from the infomercial world to be appropriated within society. In the USA the infomercial psychic Miss Cleo who had practised her 'art' for some years prior to her infomercial work, briefly became part of American popular culture. As Jonathan Bernstein (2002) noted:

References to her have popped up on various sitcoms, and she's been
parodied on those ever-popular skits between tracks on hip-hop albums
(most recently by Redman and Ludacris); Stone Cold Steve Austin even
included a parody of her in one of his WWF monologues. (Bernstein,
2002, p.98)

One of the key factors with such personalities, however, was that their association with infomercials typically signified a credibility deficit that was difficult, if not impossible, to overcome. It is no surprise, therefore, that there are few examples of an infomercial personality truly breaking into the quotidian celebrity sphere. This highlights an important reason to focus on Suzanne Paul as a case study: she is one of the very few who negotiated this transition with any degree of (albeit partial) success.

Once the 'new generation' infomercials had been established onscreen, however, it became clear there were two main intersections between the world they represented and the world of celebrity as it was generally understood. First, there were celebrities who used an infomercial to relaunch their career (most commonly not in their original field but in an unrelated area). The best example here would be George Foreman who used the infomercial format to promote his eponymous 'Lean mean grilling machine'. This was a worldwide success, with Foreman and Salton Incorporated generating more than US\$200 million in sales of the product range over four years in the mid-1990s (Brown, 1999, p.56), and Foreman's image and persona being reinvented as his professional boxing career finally ended. Second, appearing in an infomercial can be interpreted as a sign that a celebrity has fallen to new depths in their career. Examples here include Olivia Newton-John, who promoted a skincare range in 1996 (thefreelibrary.com, u.d.) and Jessica Simpson who was singled out as being particularly desperate for fame when she became a face of the acne treatment Proactiv (Netherby, 2010, p. 18-19). For our purposes, the instructive issue in both cases is how the positive and negative framing of celebrity connection to and participation in an infomercial can be (at least partially) 


\section{CELEBRITY AND SCANDAL}

located in the framework of 'scandal'. For celebrities like George Foreman, who were perceived to have made significant amounts of money, one reading of the popular reaction to their success is that their name-and persona-is the only attractive component of the package they present. In a crowded market for home grilling machines, Foreman's version only has the unique selling proposition of his name and face. For those like Olivia Newton-John and Jessica Simpson, one reading of the marker of failure that the infomercial connotes represents a significant repositioning within the world of celebrity. They have become sufficiently marginal within that world that their names and faces can be associated with one of the least credible forms of advertising.

It is this lack of credibility that underpins infomercials' second, perhaps more compelling association with scandal: the inherent suspicion with which they were positioned within popular culture. Simply put, the infomercial form (and its various textual and programmatic features, such as the hyperbolic demonstration of a kitchen knife cleanly cutting an aluminium can and the phrase 'But wait! There's more') became shorthand for a communication format that was marked by poor quality products, dubious ethics and insincerity (Dick, 2003, p.10). This manifested because of failings in three areas. First, the quality of the goods they advertised typically fell short of the promises contained (or implied) in the advertisement (Agoglia, 1999, p. 18). Second, the tendency for the companies who used them to fall foul of regulators, particularly in respect of claims of successes and personal transformation (Direct Marketing, 1997, p. 7). Third, the perception that infomercial company owners were oriented to short-term profit as opposed to long-term relationship building was reinforced by the significant number of companies that lost money, went into liquidation or simply disappeared (Gattuso, 1996, p.10).

Against this backdrop, it is perhaps unusual for any individual to become more than marginally famous or to even attempt to move into mainstream popular culture. For a variety of inter-connected reasons, however, Suzanne Paul was ideally, and arguably uniquely, placed to work against this trend. On the one hand, her carefully constructed persona combined a frank (apparent) honesty with the ability not to take herself particularly seriously. On the other, her responses to controversies, setbacks and scandals were sophisticated - and genuine - enough to reinforce her persona and, crucially, militate against the expected outcomes an 'infomercial celebrity' might expect to face.

In developing our reading of Paul's career we have analysed published 
primary sources and looked to the work of Ruth Penfold (2004) in two key areas. First, we are basing our understanding of Paul's role in her own career as a celebrity on Penfold's (2004) appreciation of the role of performativity within identity construction, where:

identity becomes the effect of performance, allowing for both agency and processes of subjugation. Identity is not something that is passively shaped, but elected (although often only partially) and seized upon. (Penfold, 2004, p. 292)

Second, Penfold highlights the role of the mass media (in which celebrities must function in order to be visible and thereby function as celebrities) in first working to construct the public (and increasingly private) life of the celebrity as a narrative which easily fits into pre-existing tropes and then positioning them as the subject of the audience's gaze in order that 'various forms of victimisation' (p. 300) can play out and, in doing so, reconfirm the narrative arc. In this context we will argue that, despite her liminal status on the edge of mainstream popular culture, Paul was able to experience 'her' narrative along the trajectory of success to scandal, failure and disgrace and, unusually, resurrect her career and her celebrity self, if not to her original status, then at least back to a position of relative respectability.

\section{Act I: The penniless product demonstrator makes a mint}

Although during the 1990s there were a number of people who developed a public profile as a result of fronting or appearing in infomercials (for instance, Neil Martin and Lisa Dow), Suzanne Paul remains the most clearly identifiable local infomercial celebrity. An emigrant originally from Wolverhampton born Susan Barnes, she had a 17-year background in sales and looked to work in that area when she came to New Zealand in 1990 (Gregg, 1996, p. 3). In one sense, then, it could be argued Paul was an economic migrant, albeit from a British, rather than a developing world background. Of course, New Zealand has welcomed successive generations of emigrants from the UK throughout most of its colonial and, later, independent history. Within the context of the later 20th century, Paul fits within the cultural milieu of the ' 10 pound Pom' - a designation for British people who came to New Zealand (and Australia) from the 1950s onwards to remake their lives in a new society (King, 2004). During Paul's time working 


\section{CELEBRITY AND SCANDAL}

the outdoor markets of Auckland she met a local entrepreneur-Paul Meier - who became her business partner (and briefly life partner) and they promoted a range of novel household and personal care items (notably massage pillows and Natural Glow face powder) at markets, trade shows and shopping malls. Then they filmed their first commercial — for Natural Glow — and ran the operation from home. Two commercials followed - for the Massage Pillow (small pillow with a battery-powered motor) and the Suzanne Clip (a brooch/clip combination for scarves and wraps) - before the business was established 'properly' (Hansen, 1996, p. 54-55). Meier provided the majority of the business experience - accordingly, he owned 80 percent of Prestige Marketing - and Paul was the spokesmodel and company 'face' (Sunday Star Times, 1996, p.A1).

From her emergence on New Zealand television in 1992 until mid-1996 Suzanne Paul was known by her birth name-Susan Barnes. According to Paul Meier, the 'Suzanne Paul' persona was developed for two reasons. First, he felt that 'Suzanne' connoted a more upmarket, aspirational set of associations than 'Susan', which he felt was relatively common. Second, he wanted the company's spokesmodel to represent both Barnes and himself-hence the use of his forename as the surname 'Paul' (pers. comm. February, 1996). Unsurprisingly, however, the similarity and overlapping inherent in 'Susan Barnes representing Suzanne Paul' was too difficult to maintain on television. Audience members (and, then, presenters and producers) began to call Susan Suzanne. After some months of resisting this 'imposition', she decided to clarify the 'brand message' and adopted Suzanne Paul as her professional name (pers. comm. March, 1996). By June of that year she had further integrated the brand persona with her private self by formally changing her name via deed poll. Here we can determine a pragmatism that has arguably been a key factor in Paul's success. Rather than persist with what had come to be perceived as an artificial division between her 'self' and the spokesmodel role, she embraced the change and reinterpreted her persona publicly.

This persona also retained a sense of the 'ordinary person' who, through dint of her own hard work and business acumen succeeded, almost despite herself:

When Suzanne Paul recorded her first television advertisement, she vomited before and after the shoot. Here she was on the verge of making the fortune she'd spent 20 years searching the world for, and she was 
scared. It had never been her ambition to be on television anyway. But she battled on, as she always has, and created a rags-to-riches cliché she is now struggling to shake off, yet keeps fending off with anecdotes from her past. Now the battling's over, it's as if Suzanne's life has just begun. (Hansen, 1996, p. 52)

This was the dominant tone of the coverage Paul benefited from in the early to mid-1990s. And it presented an opportunity for her to deepen the complexity of her persona within the celebrity culture of the time. Another key aspect here was her willingness to 'take [her] lumps' (pers. comm., 1996) and play along when she, or her products, were the butt of the joke. As one example, unlike previous (and many) subsequent 'winners' of the Fair Go (a New Zealand consumer advocacy television programme. 'Worst Ad of the Year Award', Paul accepted the invitation to appear on the programme, receive the award in person and treat the occasion seriously but lightly (ibid). In other attempts to raise her profile Paul started to reach out into other areas of popular culture. She sponsored a comedy trio in the Wellington Fringe Festival (Lane, 1996, p. 24), became an icon among the gay community and featured as a regular after dinner speaker (Hansen, 1996, p. 58).

Then in July 1996 Prestige Marketing was sold to National Media Corporation (one of the top three American infomercial marketers) for NZ\$39 million in cash and stock options. Paul was foregrounded in the attendant publicity, which in large part depended on the curiosity factor of a major international company paying a large sum for a relatively low end marketing operation, (see, for instance, Bell, 1996; Gregg, 1996; Hill, 1996) and she and Meier became part of the commercial elite when they entered onto the annual National Business Review richlist:

This is a classic rag-to-riches story. In fact, the life of Susan Barnes would make a perfect plot for a Jackie Collins blockbuster. From the slums of Wolverhampton in the English Midlands to the leafy slopes of Remuera, Auckland, our heroine struggled to beat the odds and became a junk millionaire (keep an eye out for the miniseries). (National Business Review, 1996, p. 11)

Ironically, given the ownership structure of the company (Paul only owned 20 percent of the business), Paul was given the majority of the credit for Prestige Marketing's success:

PACIFIC JOURNALISM REVIEW 19 (2) 201355 


\section{CELEBRITY AND SCANDAL}

Infomercials such as hers are the new wave of advertising, threatening the death of the 30-second commercial and creating unprecedented demand for the most unlikely products. Who would have predicted a chirpy, petite Englishwoman with an accent people sniggered at could put Natural Glow's 'thousands of luminous spheres' on the faces of countless New Zealand women? That an apparently ridiculous advertisement could move truckloads of FloraZanne vases? That the innocuous, diminutive Suzanne Clip (which Suzanne cannily named after herself, not to mention devising the myriad scarf tying methods) could become one of the most-discussed products of our time? That Suzanne herself could become a cult figure just by hawking bizarre merchandise? (Hansen, 1996, p. 56)

This arrangement almost certainly benefited Paul and Meier equally (she could become the public face of the company and he could concentrate on running and directing its operations). However, once the sale had taken place, Paul became somewhat sidelined within the company and began to develop her career outside it (Infomercial company marketing executive, pers. comm. 2003). In this environment Paul began to actively parlay her infomercial celebrity status into a mainstream television career.

Act II: Pushing into the mainstream — and the mainstream pushes back As a result of her increased status as a business success story, by early 1997 Paul was one of the 'most sought-after personalities on the [after-dinner] speaking circuit' (Earle, 1997, p. 41). In this process her cultural capital reached significant heights: her speaking rate-NZ\$3500 — was the same as ex-Prime Minister David Lange and ex All Black captain Sean Fitzpatrick (Hartnell, 1997, p. 8). To celebrate her 40th birthday she recorded and released the Chas and Dave hit Life Begins at 40, which charted in the New Zealand top 20 (Dix, 1997, p. 21). Again, this shows the interestingly contrary nature of Paul's appeal-rather than obfuscate or mourn her age she publicly commemorated the occasion with a comic song that referenced her English background. Later in 1997 Paul followed Life Begins at 40 with a much less successful release-The Blue Monkey, a sanitised dance song that both parodied her attempts to fit within popular culture and attempted to position her within youth culture ${ }^{1}$. That same year Paul was one of the 'celebrities' whose reaction to the death of Princess Diana formed part of 
the local media coverage as that media event unfolded. Paul felt she had a particular connection to the Princess, in that she had bought an item donated by Diana at a charity auction. For that reason, and her general emotional reaction to the death, Paul 'cut short' a holiday to watch the funeral live on television. There was no suggestion she was unable to access the coverage while on holiday; rather, Paul wanted to be in the comfort of her own home as she experienced the grief of the funeral (Reid, 1997, p. 3).

The year 1997 also saw Paul marry for the first time, to her much younger partner Dean Kilworth. Although the age difference arguably heightened public interest, at this point in her career Paul was sufficiently newsworthy that her wedding would have been covered in any case (Newspaper editor pers. comm. October 1997). The celebrification of this event was confirmed by the fact the couple negotiated a commercial deal where the rights for exclusive coverage were sold to the Woman's Day magazine (Barclay, 1997, p. A1). This fact then entered into the narrative, with other media (especially other print outlets) commenting on the over-the-top security required to preserve the exclusivity of the deal (Cleave, 1997). Here we can see perhaps the apogee of Paul's move into mainstream celebrity - newspapers featured her marriage and the rights deal for its coverage as front page news and the provocation for a wider discussion about journalism ethics, local celebrity culture and the taste of the reading public.

Issues of taste (and, arguably, cultural capital) came to the fore with Paul's first major mainstream television venture, the announcement of which was carried in the serious business press (National Business Review, 1996a, p. 53). Sponsored by the same magazine that bought the rights to her wedding, the programme was the Woman's Day Style Challenge, which was based around Paul playing 'fairy godmother to the common people, giving ordinary New Zealanders the chance to be 'transformed' with a makeover and new clothes (Marketing Magazine (Fastline), 1997, p. 4). The show developed from Paul's reaction to watching the makeovers on The Oprah Winfrey Show. Her insight was that the drama and pathos could be expanded upon, and she wanted hers to be 'more emotional' (Pepperall, 1997, p. 21). Paul's position that the Oprah Winfrey show could be made more heartrending is, on one level, astonishing. At the time 'Oprah' was self-consciously one of the most demonstrative and deliberately poignant shows on television. In effect Paul's makeovers on Woman's Day Style Challenge operated from a tabloid paradigm. The tone of

PACIFIC JOURNALISM REVIEW 19 (2) 201357 


\section{CELEBRITY AND SCANDAL}

the programme can be indicated by the women chosen to be made over- 'the former nun whose family says she still looks like one, female prison guards and a woman fighting cancer' (Kennedy, 1997, p. 21).

The overtly dramatic nature of the programme intensified interest in Paul and her television career (See Cleave, 1998b, p. 1; Simpson, 1998a, p. 51; The Evening Post, 1998, p. 3; Wakefield, 1998, p. 18). In this light, her decision to move from TV3 to TVNZ for the 1998 season, which was almost certainly linked to a disagreement between Prestige Marketing and CanWest (TV3's then owner) over infomercial rates on TV3 and TV4 sparked threats of legal action by CanWest as her new show_Guess Who's Coming to Dinner? —was almost identical to Woman's Day Style Challenge (Drinnan, 1997, p. A11). Ultimately, the networks chose to resolve their differences via a series of toplevel meetings rather than risk an increase in 'outside' regulation (Simpson, 1998 b, p. 52). Although some liked the new programme (for example, see Sunday News, 1998, p. 31), critics were generally scathing.

It's hard to imagine the worst scenario-Suzanne Paul inspecting your fridge, or Suzanne Paul rummaging through your wardrobe. In the first, she gets to let some cheerful insults fly when she spots the end of last month's cheese simmering at the back of the second shelf and those rubbery carrots lurking at the bottom of the vegetable drawer. In the second, she gets to criticise your taste, pull out clothes you no longer fit into, and show the nation the fashion disaster you bought that was too expensive to ever throw out. Either of those possibilities is enough to ensure that many a woman confronted by Suzanne at the door would slam it and run, but obviously there are some braver families around New Zealand. (Mackay, 1998, p. 19)

Such comments were by no means untypical (see also McOnie, 1998, p. 6; New Zealand Herald, 1999, p. 22) and illustrates the widespread belief that Guess Who's Coming to Dinner? and Paul were symptomatic of a general decline in television standards (The Southland Times, 1999, p. 30). At one extreme the show was explicitly likened to a 'home invasion' in review (Herrick, 1998, p. A11). 'Home invasions' (in reality, aggravated burglary) were the subject of mild press hysteria during 1998 (Matthews, 2001).

Such connotations were relatively widespread - witness The New Zealand Listener cartoon satirising the state of television in New Zealand in which 
Paul featured twice: once as 'Suzanne Paul invades the privacy of unsuspecting individuals with hilarious results!' and once as 'Suzanne Paul performs unnecessary surgery on unsuspecting individuals with hilarious results' (The Listener, 1998, p. 10). On a more serious level, it was also argued that Paul was responsible for the rise of makeover shows in the late 1990s, as she legitimised their infomercial-influenced format by her presence on mainstream television (Cleave, 1998a, p. 19). Nevertheless, Guess Who's Coming to Dinner? remained sufficiently popular with viewers to be recommissioned for the 1999 season (The Press, 1999, p. 18).

Paul's celebrity status was further legitimised when her private life became newsworthy in its own right (rather than in reference to her television career or as the result of a commercial deal). For instance, in 1998 Paul's first husband had a series of failed businesses and at least two assault convictions was front page news (Lose, 1998a, p. 1; Lose, 1998b, p. 3). And the pattern was repeated in 2002 when her second husband was revealed to be an ex-bankrupt with a criminal record who had defaulted on child support payments (Lose \& Umbers, 2002 , p. 7). However, on balance the coverage was positive. For instance, Paul was regularly included with other 'top' TV personalities in wider popular culture - witness the 1998 charity calendar in which celebrities revealed their 'inner children' to aid a child cancer appeal (The Evening Standard, 1998, p. 15; Grunwell, 1998, p. A7; Umbers, 1998, p. 3). She was also chosen-along with other celebrities, politicians and 'some of New Zealand's well known writers' - to share her 'favourite experiences with books' for the re-opening of an historic library in New Plymouth (Knightbridge, 1998, p. 12). Interestingly, her status here was negotiated to some degree-when a pot she had painted for another auction broke in transit, the organiser commented, 'I think it's in keeping with Suzanne Paul and her personality really. I mean that in the nicest possible way' (Sandy Galland quoted in The Timaru Herald, 1998, p. 2). The most obvious unspoken association here is with poor quality goods and their delivery to buyers' homes.

Of course, Paul's links with the infomercial business could easily be legitimised within mainstream culture. Outtake footage from her first shortform infomercials featured in a 1999 compilation Look Who's Famous Now, which focussed on early appearances by household names (The Dominion, 1999a, p. 23). Later that year Paul was one of the nominees in the best entertainment or comedy performance in the New Zealand Academy of Film 


\section{CELEBRITY AND SCANDAL}

and Television Arts' annual television awards (The Dominion, 1999b, p. 27). Paul's story remains featured on the official website of the New Zealand government's immigration service as a 'migrant hero'. Her specific textbox read: 'Came from England in 1991 with $\$ 18$ and a dream. She developed a highly successful company which she sold in 1996 for $\$ 39$ million'. ${ }^{2}$ In the 2000-2001 season Paul was the star of another show-Second Honeymoonin which children wrote in to ask for their parents to be given a holiday while Paul and her team looked after the house and children (Sparrow, 2000, p. 4). Again, this was not a critical success and its faults were explicitly linked to Paul's infomercials.

With her grating working-class Pommy voice and her incessant flow of off-the-cuff chatter, the budgie entertained and charmed the masses. She literally became the 'sale of the century' and no handbag or bathroom cupboard was complete without a pot of her wretched Natural Glow. Paul was single-handedly responsible for putting a blush on the cheeks of thousands of pasty-faced Kiwis, and wreathing a nation of ageing female red necks in her natty scarves. Somehow, in spite of her awfulness, we fell in love with Suzanne Paul and Paul couldn't believe her luck. Feature-length newspaper articles were written about the girl-Barrymore sensation and not a week went by without the chinless wonderette peering out from the pages of a women's weeply. Good on her. She flogged hard and deserved her success but let's face it, it's time for the budgie to stop chirping. (Bowron, 2001, p. 18)

Nevertheless, despite the obvious derision to which she was subjected (and her 'downgrading' as a celebrity), Paul did not disappear from New Zealand screens. In 2002 she was one of the panellists on How's Life-an advice show which screened immediately preceding the weeknight news (The Evening Post, 2002, p. 7). The show did not rate well (McLean, 2002, p. A5), and was a critical disaster (Daniell, 2002, p. 14; Stevens, 2002, p. 21). Yet in 2003 she was one of the contestants on Celebrity Treasure Island, a reality programme in which celebrities compete to win money for charity (Sunday Star Times, 2003, p. A7).

The most significant event in Paul's demise, however, was the collapse of her ill-advised and poorly thought through tourist venture-Rawaka - in mid 2004. Initially designed to revitalise the iconic 'Fisherman's Wharf' restaurant beneath the north-west aspect of the Auckland Harbour Bridge, Rawaka was

60 PACIFIC JOURNALISM REVIEW 19 (2) 2013 
Paul's attempt to cater to (alleged) tourist demands to experience a Māori cultural centre in central Auckland (Gregory, 2003, p. A4). It soon became clear, however, that Paul was not equipped to develop this project:

It has got warriors in dry ice, a cash bar under the stage and polystyrene animals carved by her fiancé but TV star Suzanne Paul's new Māori tourist venture hasn't impressed its cultural advisors. The Natural Glow millionairess is facing criticism for a 'cabaret meets kapahaka' dinner show which critics say is clichéd and inappropriate. (Sunday Star Times, 2004, p. A1)

As the Rawaka story developed, the media coverage tended to focus on implicit connections between Paul's association with infomercials (and their inherent cheapness and lack of quality) and her inability to understand why her new venture was not well received. (See, for instance, Rapson, 2004, pp. 66-71). Further, the disconnect between Paul's status as a migrant and the self-belief she displayed in producing an authentic Māori 'experience' provided an obvious opening for a scandal narrative to develop. (See, for example, Hewitson, 2004, p. A18). Here, the main point was that Paul has overreached herself both culturally (in thinking she could repackage Māori performing arts and crafts in a similar method to the products she advertised via infomercials) and commercially (in mis-reading the market and failing for the first time in her career in New Zealand) (Middlebrook, 2004, p. A4). The final phase of this act of the Suzanne Paul narrative was relatively straightforward. After it became clear that Rawaka could not meet its obligations to creditors (Perrott \& Kiriona, 2004, p. A3), Paul was left with no alternative but to declare bankruptcy with personal liabilities of at least NZ\$1.6 million (McNabb, 2004, p. 3).

At this point - mid 2004 - it could be argued that Paul (and her narrative) had moved through a relatively standard celebrity arc, where the characteristics that underpinned and typified her fame moved to be the main drivers of criticism and approbation. Here, we can see the optimistic new migrant who made a fortune becoming the out-of-touch, culturally unsafe wastrel. And when considering the major driver of her initial success - business acumen - the scandal associated with bankruptcy would normally be too great for someone in Paul's position to recover from and / or redeem themselves. The next act of her narrative, however, demonstrated that the condemnation of her fall from grace was perhaps as unrealistic as the lauding of her original achievements. 


\section{CELEBRITY AND SCANDAL}

\section{Act III: The made-over make-over queen}

It is, of course, normal for a celebrity who 'falls victim' to a scandal, especially one for which they are at least partially responsible, to disappear from the public gaze (perhaps after attempting a 'comeback' of some kind). In Paul's case, the narrative of redemption (of sorts) began soon after the Rawaka venture ended in ignominy. Within a year of her disgrace Paul had returned to her pre-infomercial career of being a product demonstrator in shopping malls and markets. Of course, this was newsworthy in its own right, and could be a continuation of the 'fall from grace' story arc, where the former celebrity readjusts (often badly) to their new situation. Suzanne Paul, however, reacted very differently. In one of a surprising number of news articles and features in the months after her bankruptcy, (a search of online newspaper databases returned more than 80 articles featuring Paul in the 10 months immediately after Rawaka folded), Paul's resilience and humour were praised and, as she put it:

It doesn't really worry me ... if you lose money you can always get it back ... I'd rather have my health and my loved ones. Just keep positive, keep your sense of humour, put things into perspective. It's not the end of the world ... but if you can just look around, there's so many people worse off. (Suzanne Paul quoted in Roxburgh, 2005, p. 8)

Paul's acceptance of her situation, her good humour and her often-stated aim to repay her creditors earned her significant acceptance, none more so than the 'Best Honourable Behaviour' Award in the Metro Magazine 'Best of Auckland 2006' edition (Metro, 2006, p. 41).

As a result of her partial public rehabilitation, Paul was chosen as one of nine celebrities to feature on Intrepid Journeys, a lifestyle travel programme where famous faces travel to meet 'real' people in overseas countries (TVNZ executive pers. comm. July 2011). The programme screened on the most popular, serious channel (TVOne) and marked a new phase in Paul's career, as Intrepid Journeys was predominantly a vehicle for the 'star' and the audience to (a) learn more about a foreign culture, and (b) reflect - even implicitly — on the benefits of living in New Zealand (as well, of course, as being an interesting travelogue in its own right). Paul's episode highlighted her optimism and allowed viewers to see that her real (if still obviously constructed) persona remain authentic as she endured the hardships and dangers of her 
overland journey in Asia (New Zealand Herald, 2007b, p. A10). Importantly, there was no substantial critical or popular feedback that Paul did not deserve her place in the programme, which reinforced her regaining celebrity status, if only partially.

The media event that most assisted Paul's rehabilitation, however, was her participation, and eventual victory, in the third series of TVNZ's Dancing with the Stars. On one level, it is obvious that participating in such a programme denotes a certain level of celebrity - the 'names' need to be recognisable (enough) to fit within the general ambit of the show. On another level, her participation was also easily explained - she easily fit into the 'mature(er) female' category for the programme's casting (along with the politician, the sportsman, the singer, the actress and so on). Most of the coverage situated Paul in the context of the successful phase of her career - referring to her as 'Infomercial Queen Suzanne Paul' was relatively common. (See, for instance, New Zealand Herald, 2007a, p. A3). During the 12-week series Paul was consistently shown to be taking the show-and competition seriously-while never taking herself seriously. The ability to laugh at her own voice, mistakes and ability to hurt her partner became a recurring theme of the programme. This approach, and her improving ability to dance, clearly worked as Paul was consistently voted into the next round, and then as the overall winner, by the viewing audience. After her victory, against a much younger female singer, the coverage of Paul's success was almost universally positive. As one newspaper report put it: 'She was simply sizzling and it was her night' (The Dominion Post, 2007, p. A1). In winning Dancing with the Stars Paul joined popular culture royalty in New Zealand, as the previous winners were a former All Black (series one) and the only New Zealander to win Miss Universe (series two). She also reinforced her persona as authentic by being candid about her belief that victory would give her the necessary publicity to launch a new phase of her career to pay off the Rawaka creditors (The Nelson Mail, 2007, p. 15).

However, despite the reputational rehabilitation, Paul was not able to reach her previous heights. Attempts to position herself as a motivational speaker and/or life coach did not lead to particular success, although they were taken seriously enough for Penguin Books to publish her hybrid autobiography / motivational book in 2008 (Paul 2008). The title-But wait, there's moreplayed on her infomercial days (it was her catchphrase on many commercials) but also reinforced the narrative that Paul was neither finished nor giving up. 


\section{CELEBRITY AND SCANDAL}

Magazine cover stories (see, for instance, Daly, 2008) continued to support her narrative of a hard-working, ordinary person who continued to be positive, to achieve her goals, and to 'make it happen'. In subsequent years Paul parlayed her dancing success into a short-lived professional acting career (Ross, 2010, p. 4) and remained sufficiently in the public eye that her reactions to major events were newsworthy. For example, she was one of the 'names' whose tweets in response to the Christchurch earthquake disaster in 2010 formed part of the media coverage (New Zealand Herald, 2010, p. A7).

\section{Epilogue: Scandal, transgressing the persona and redemption?}

On the most basic level, Suzanne Paul's story is one she created. In all its phases she demonstrated sufficient intent and media literacy that any (self) denials of agency would be implausible. Perhaps her success at being able to reinvent her persona and her 'self' after a significant public failure lies in her psychology or her entrepreneurial spirit. Yet, as she herself admitted, such characteristics are required by any successful businessperson (Paul, 2008, p. 15). It is more likely that, because Paul's career constantly interacted with (potential) scandal — be it the dubious infomercial industry, the lavish spending, or the bankruptcy - she consistently followed a narrative where her main reference point was a site of cultural transgression. In this context, in order to remain even partially legitimated, Paul was required to present and project a knowing celebrity, and one that purveyed every aspect of her public life. In doing so, she usefully recognised the need for an authentic connection with the ordinary and the everyday - for instance, even when it was clear that her career was not going to re-establish itself to its former glory after 2008 her dreams remained and she was unashamed to recount them (Daly, 2008, p. 23). Living an ultimately unsuccessful life (if only judged against her own goals and aims), Paul nevertheless retained enough genuine mana to connect meaningfully with audience members, both in person as she returned to her 'roots' and demonstrated in shopping malls (Roxburgh, 2005, p. 8) and in mediated form. The publicly funded nzonscreen website featured Paul as one of its Kiwi stories (along with other iconic people or topics). In the interview Paul tells her story (again) with no bitterness or regret. She remains happy to have spent 'all' her money and sorry that her creditors are still waiting payment. But the reaction of one viewer perhaps best encapsulates Paul's appeal and serves as a fitting epilogue to her story, an epilogue that combines her 
liminal status as a non New Zealand 'Kiwi', with identifying her with and through infomercial products and, of course, her ultimate failure.

I'm an expat Kiwi living in Scotland. And while Suzanne isn't a Kiwi, she is forever the Kiwi Girl to me. I actually think about her, when I think of home, she is one of the things I miss about home. Her resilient, lively, friendly manner makes me smile and I just adore her. Suzanne Paul is home to me and I now wish I could get my hand on her Natural Glow. She's a legend and I love her and I wish her all the best and hope she gets all the support and love in the world. Kia Kaha Babe, we love u. ${ }^{3}$

From another, more critical, aspect, Paul's trajectory speaks to her astute adaption to the demands of the market. Hers is a striking example of the virtues of embracing the serial role of the celebrity as factotum and doing so with the zeal of the survivor. Such a role clearly requires a performance of a marketable self or self-commodification. Often self-commodification entails carving out an identity for others that still leaves a space for the self (Bunten, 2008). Self-commodification in this sense entails the performed inscription of a distance from the self, a strategy of dignity retained, which relies on marshalling the skills of performance. Clearly Paul has not sought such a space because the role of celebrity factotum, fitting personality to the sales pitch and demands of the market, works against the notion of representation, of being another. In her case there is a minimum of specialisation in this craft-centred sense, rather she presents herself as herself in order to be employable - even when she is employing herself. Such a presentation clearly involves skills of interaction on camera that are the zero-degree of celebrity. Her kind of celebrity - the thin ever-mobile — sits uneasily with the role of representing a grounded cultural form such as the Rawaka venture, and so it was there that the creature of the market ran out of market.

\section{Notes}

1. The Blue Monkey music video was available on September 7, 2013, at www. youtube.com watch? $\mathrm{v}=\mathrm{NOUE} 41 \mathrm{RjU} 7 \mathrm{o}$

2. www.immigration.govt.nz/community/stream/employ/quickcheck.htm Accessed January 92006.

3. Comment by 'Spirit Child' approx June 2013 on nzonscreen interview. Available at: www.youtube.com/watch?v=8U6jFiLdL-o Accessed August 5, 2013.

PACIFIC JOURNALISM REVIEW 19 (2) 201365 


\section{CELEBRITY AND SCANDAL}

\section{References}

Agoglia, J. (1999, June 4). Fitness quest sales on track despite FTC woes. Sporting Goods Business, 32(9), 18.

Barclay, C. (1997, April 13). Susan's all aglow for her top show. Sunday Star Times. p. A1.

Bernstein, J. (2002, February 23). The Guide: Jonathan Bernstein's aerial view of American tv. The Observer, p. 98.

Bell, C. (1996, June 8). \$39m sellout caps rags-to-riches story. The Dominion, p. 1. Bowron, J. (2001, March 8). Paul and Parker: Dumb and dumber. Press, p. 18.

Brown, E. (1999, March 8). Ooh! Aah! Forbes, 163(5), New York, p. 56.

Bunten, A. (2008). Sharing culture or selling out? Developing the commodified persona in the heritage industry. American Ethnologist, 35(3), 380-395.

Carvell, T. (1997, May 26). A star is born in the wee hours. Fortune, 135(10), 36.

Cleave, L. (1997, April 13). But hired heavies tried to give us the brush off. Sunday News, p. 1.

Cleave, L. (1998a, September 4). Ginette gets down and dirty. Sunday News, p. 19.

Cleave, L. (1998b, March 2). TV3 sees similarities between shows. Sunday News, p. 1.

Daley, D. (2008, September). Chasing dreams. Australian Women's Weekly, pp. 18-23.

Daniell, S. (2002, May 29). How's Life should get a life. Evening Post, p. 14.

Dick, B. (2003, June). Watch TV and become good-looking and rich. Broadcast Engineering, 45(6), 10.

Direct Marketing.(1997, February). Hawthorne Communications settles FTC charges, pp. 6-7.

The Dominion. (1999a, February 27). Kiwi celebs - the way they were, p. 23.

The Dominion. (1999b, October 14). Duggan, Lawless up for awards, p. 27.

The Dominion Post. (2007, April 30). Strictly Paul-room, p. A1.

Drinnan, J. (1997, September 14). Networks set for scrap over unsigned talent. Sunday Star Times, p. A11.

Dix, J. (1997, May 30). Top of the pops. Truth, p. 21.

Earle, V. (1997, October). Desperately seeking gurus. Management Magazine, p. 41.

The Evening Post. (1998, March 23). Guess who could be coming to court?, p. 3.

The Evening Standard. (1998, October 14). Project aims to raise profile of cancer research, p. 15.

The Evening Post. (2002, April 8). Advice on how to enjoy life, p. 7. Retrieved on August 5, 2013, from www.thefreelibrary.com/Olivia+NewtonJohn+Introduces+ Revolutionary+SkinCare+Line-a018709111

Gattuso, G. (1996, May). DRTV host charged in pyramid scheme. Direct Marketing, 59(1), 10.

Gregory, A. (2004, November 11). Cultural glow to perk up old restaurant. New Zealand Herald, p. A4.

Gregg, S. (1996, June 16). Suzanne’s \$39m glow. Sunday Star Times, p. A3.

Grunwell, R. (1998, October 11). 'Big kid' fantasies. Sunday Star Times, p. A7.

Hartnell, D. (1997, July 25). What it costs to have a celeb at your party. Truth, p. 8.

66 PACIFIC JOURNALISM REVIEW 19 (2) 2013 
CELEBRITY AND SCANDAL

Hansen, J. (1996, August). Suzanne Paul: The woman who can sell anything. Metro, pp. 52-59.

Herrick, L. (1998, December 27). The long and short of '98'. Sunday Star Times, p. A11.

Hewitson, M. (2004, April 17). Steak, chips and Maorioke with Suzanne Paul. New Zealand Herald, p. A18.

Hill, D. (1996, June 7). Suzanne sells out for a cool \$39m. The National Business Review, p. 1.

Johnson, R. (2013, May). The emergence of the infomercial in New Zealand 19931997. The Political Economy of Communication. Retrieved August 5, 2013, from http://polecom.org/index.php/ polecom/article/view/12/126

Johnson, R., \& Hope, W. (2004, August). What is an infomercial? Advertising and Society Review, 5(2). Retrieved on August 1, 2013, from http://muse.jhu.edu. ezproxy.aut.ac.nz/journals/advertising_and_society_review/v005/5.2hope_johnson.html

Kennedy, E. (1997, April 21). Preview. The Dominion, p. 21.

King, M. (2004). The Penguin history of New Zealand. 2nd ed. Auckland: Penguin.

Knightbridge, L. (1998, October 13). Historic building set for new millennium. The Daily News, p. 12.

Lane, M. (1996, March 2). Titillating women bust into town. The Evening Post, p. 24.

The Listener. (1998, April 4). Meantime (cartoon). p. 10.

Lose, J. (1998a, June 7). Beating victim says she should sue. Sunday News, p. 1.

Lose, J. (1998b, June 14). Guess who bashed a wedding guest? Sunday News, p. 3.

Lose, J. \& Umbers, L. (2002, December 1). Guess who's dating an ex-bankrupt? Sunday News, p. 7.

Mackay, L. (1998, March 10). Inspections a Paul. The Southland Times, p. 19.

Marketing Magazine (Fastline). (1997, April 17). New Zealand Women's Day. p. 4.

Matthews, L. (2001) Home invasion: The role of the New Zealand media in a moral panic case study. Unpublished MA thesis, Auckland University of Technology.

McLean, R. (2002, May 5). How's Life no ratings beast. Sunday Star Times, p. A5.

McOnie, J. (1998, May 9). NZ-made television shows so lacking in quality it's laughable. Waikato Times, p. 6

McNabb, D. (2004, July 21). Suzanne Paul owes \$1.6m. The Independent, p. 3.

Metro. (2006, December). Best of Auckland, pp. 36-49.

Middlebrook, L. (2004, June 27). Jaded setting for cultural radiance. Sunday StarTimes, p. A4.

The National Business Review. (1996a, November 22). The bluffer's guide to TV3's new season, p. 53.

The National Business Review. (1996b, July 19). Suzanne's big windfall produces natural glow, p. 11.

The Nelson Mail. (2007, June 2). Murder, as always, on the dance floor, p. 15.

Netherby, J. (2010, August 28). Tapping into: The zit-geist. Billboard, p. 18.

New Zealand Herald. (2010, September 8). SPY: Celebrities tweet about Christchurch. p. A7. 


\section{CELEBRITY AND SCANDAL}

New Zealand Herald. (2007a, April 18). Ieremia voted off while Laws dances on despite lowest score. p. A3.

New Zealand Herald. (2007b, February 19). Monday's TV highlights. p. A10

New Zealand Herald. (1999, January 1). Lot of twaddle in local tellyland. p. 22.

Paul, S. (2008). But wait, there's more. Auckland: Penguin.

Penfold, R. (2004). The star's image, victimization and celebrity culture. Punishment and Society, 6(3), 289-302.

Pepperall, S. (1997, June 25). Sellebrity Suzanne. Waikato Times, p. 21.

Perrott, A., \& Kiriona, R. (2004, July 14). Accountant has mail for Suzanne Paul's troubled venture. New Zealand Herald, p. A3.

The Press. (1999, August 14). Suzanne's back, p 18.

Rapson, B. (2004, February). Show girl. Metro, pp. 66-71.

Reid, N. (1997, September 10). Rosebud in trinket box a memorial to Diana. The Evening Post, p. 3.

Ross, F. (2010, June 17). Tapping into some NZ characteristics. Taranaki Daily News, p. 4.

Roxburgh, T. (2005, April 28). Humour and attitude secret to Paul's glow. The Southland Times, p. 8.

Simpson, M. (1998a, March 27). Allegations of copyright shows fire up channels. National Business Review, p. 51.

Simpson, M. (1998b, May 28). Legal sharks bare teeth as copycat fight brews. National Business Review, p. 52.

The Southland Times. (1999, January 2). Time for viewers to ask about the direction of NZ television, p. 30.

Sparrow, B. (2000, March 27). [No Headline], The Nelson Mail, p. 4.

Stevens, R. (2002, April 19). Take my advice — switch off. The Nelson Mail, p. 21.

Sunday News. (1998, August 2). Sunday News picks of the week, p. 31.

Sunday Star Times. (2004, November 1). Tiki tacky-Suzanne Paul comes unstuck with Māori plan, p. A1.

Sunday Star Times. (2003, August 17). Noel's new look book, p. A7.

Sunday Star Times. (1996, July 14). Less of a glow for Paul, p. A1.

The Timaru Herald. (1998, November 6). Picking up pieces for auction, p. 2.

Umbers, L. (1998, October 11). Daring calendar reveals celebrities' secret desires. Sunday News, p. 3.

Wakefield, P. (1998, March 11). Programmers clash over similar shows. The Evening Post, p. 18. 
CELEBRITY AND SCANDAL

Dr Rosser Johnson is chair of the University Ethics Committee and Associate Dean Postgraduate in the Faculty of Design \& Creative Technologies at the Auckland University of Technology. He holds a PhD from the University of Westminster and is currently the television area chair for the Popular Culture Association of Australia and New Zealand.

rjohnson@aut.ac.nz

Nemane Bieldt is a PhD student in the School of Communication Studies at AUT. Her thesis focuses on the impact of creative industries policy and rhetoric on the museum sector and is due for submission in early 2014.

nbieldt@aut.ac.nz

\section{PACIFIC MEDIA CENTRE}

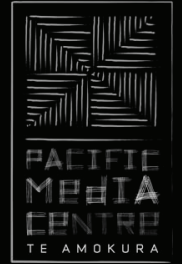

The Pacific Media Centre (Te Amokura) is the only media research and community resource centre of its kind in Aotearoa/New Zealand and has a strategic focus on Māori, Pasifika and diversity media and community development. It was established by AUT University's Faculty of Design and Creative-Technologies in 2007. having evolved from a cluster of research and community collaborations within the School of Communication Studies.

PMC activities include:

- International book and research publication

- Publication of the peer-reviewed Pacific Journalism Reviewresearch journal

- Publication of Pacific Media Centre Online as a media resource and postgraduate outlet

- Publication of Pacific Media Watch, a regional media monitoring service

- Journalism and media research opportunities

- Asia-Pacific internships for postgraduate students 